\title{
A OBRA DE ARTE: O COMBATE ENTRE MUNDO E TERRA
}

\author{
VELOSO, Ataide José Mescolin2
}

\section{Introdução}

Desde a Grécia Antiga, a questão da verdade tem ocupado lugar de destaque nas discussões filosóficas. Já na época de Platão, a filosofia estava preocupada com algumas questões que, de certa forma, já eram anteriores ao próprio pensamento platônico: O que a arte quer dizer? É ela capaz de ensinar uma verdade a respeito do mundo?

Em todos períodos da história, indagações semelhantes continuaram a preocupar os pensadores: Qual é de fato a medida? O homem? A razão? A arte? Nas tragédias gregas, autores como Sófocles colocaram em cena personagens que, acreditando no poder e no intelecto humanos, precipitam a sua ruína. É exatamente isso o que acontece em Édipo Rei, uma das mais conhecidas tragédias de Sófocles.

\section{Desenvolvimento}

A fala inicial de Édipo já demonstra o seu elevado grau de autoconfiança. Apresenta-se como uma espécie de "salvador da pólis", uma vez que foi capaz de decifrar os enigmas da esfinge, os quais ameaçavam a cidade. O seu poder é reconhecido por todos os cidadãos de Tebas e até mesmo as palavras do sacerdote contribuem para a divinização de Édipo:

ÉDIPO: (...) Não quis que outros me informassem da causa de vosso desgosto; eu próprio aqui venho, eu, o rei Édipo, a quem todos vós conheceis. (...) Quero prestar-vos todo o meu socorro, pois eu seria insensível à dor se não me condoesse de vossa angústia.

O SACERDOTE: Édipo, tu que reinas em minha pátria, bem vês esta multidão prosternada diante dos altares de teu

2Doutor e Pós-Doutorando em Ciência da Literatura (Poética) pela Universidade Federal do Rio de Janeiro. Professor auxiliar da Universidade Estácio de Sá e do Centro Universitário Augusto Motta, Professor de Língua Portuguesa e Literatura Brasileira do Colégio Brigadeiro Newton Braga (Aeronáutica/RJ, Membro do Instituto de Hermenêutica Jurídica, Membro do GT Teoria do Texto Poético (ANPOLL) 
palácio. (...) Tu, que és o mais sábio dos homens, reanima esta infeliz cidade, e confirma tua glória! Esta nação, grata pelo serviço que já lhe prestaste, considera-te seu salvador. Salva de novo a cidade; restitui-nos a tranqüilidade, ó Édipo!

(SÓFOCLES: 2000, p. 13-15)

A força e a superioridade de Édipo também se fazem presentes em outros momentos da peça. Ora confirmadas pelo próprio Édipo, que se vangloria do seu poder, ora por outros personagens, que acabam por acelerar a própria queda do monarca:

ÉDIPO: (...) Se alguém, por mero temor, deixar de indicar um amigo, ou de se denunciar, eis o que ordeno que faça, e o que ele deve saber de mim: que nenhum habitante deste reino, onde exerço poder soberano, receba esse indivíduo. Eu quero que seja para sempre maldito!

(...)

CREONTE: Ora, vejamos: tu desposaste minha irmã?

ĖDIPO: È impossível responder negativamente e tal pergunta.

CREONTE: E reinas tu neste país com ela, que partilha de teu poder supremo?

ÉDIPO: Sim; e tudo o que ela deseja eu imediatamente executo. (SÓFOCLES: 2000, p. 23 e 41)

Édipo se acha tão seguro de si que, diversas vezes, chega a abusar de sua autoridade. Nem mesmo a peste que assola Tebas consegue fazer com que enxergue o abismo em direção ao qual caminha. Para ele, a consolidação do poder e a força da razão são, na verdade, a medida de todas as coisas. Em uma das discussões com Creonte, Édipo afirma, com total segurança, que somente ele sabe o que lhe convém fazer. Declara, ainda, que a despeito das circunstâncias, todos devem sempre obedecer a ele. O abuso de poder de Édipo se manifesta, de maneira ainda mais intensa, no momento em que ele manda chamar o velho pastor de Laio. Édipo não se contém: ameaça o servo de vários modos, chegando até mesmo a apresentar requintes de crueldade. As súplicas do pobre pastor não o comovem nem um pouco:

ÉDIPO: Pois se não responderes por bem, responderá à força! O SERVO: Eu te suplico — pelos deuses! —, não faças mal a um velho!

ĖDIPO: Que um de vós lhe amarre imediatamente as mãos às costas!

O SERVO: Que desgraçado que sou! Por que me fazes isso? Que queres tu saber?

ÈDIPO: A criança de quem se trata, tu the entregaste? 
O SERVO: Sim! Melhor fora que nesse dia eu morresse! ĖDIPO: Pois é o que te acontecerá hoje, se não confessares a verdade! (SÓFOCLES: 2000, p. 70-72)

Édipo fica cego exatamente por pensar que o homem é a medida de todas as coisas. Descobre, então, a existência de um outro poder, poder este que transcende os limites do homem, que se manifesta através do "operar" da obra de arte. Em relação a tal descoberta, seria possível afirmar que Édipo se torna uma espécie de arquétipo de todo ser humano. É no momento em que o homem conclui que não existe uma relação dicotômica entre ele e a physis, mas sim uma relação de tensão de unidade como diferença.

É possível ver Édipo como o próprio ser humano como questão. Fazemse presentes nele todas as questões com as quais o homem se acha envolvido. Édipo não escolhe as questões, elas é que o escolhem. "A concreticidade de sua realidade está no agir constante e ambíguo pelo qual busca o sentido do que ele é em meio ao enigma do real, do qual ele é participante indissolúvel."(CASTRO: 2005, p. 22) Não há como Édipo escapar do seu destino. Ao tentar fugir do destino, mais ele o cumpre. A ambigüidade é uma característica inerente a todo agir essencial do homem: desejamos 0 destino e ao mesmo tempo não o desejamos.

Édipo encontra-se sempre entre o limiar do agir da sua própria vontade e o agir do saber da Moira. Édipo, assim como todo homem, encontram-se diante de dois enigmas essenciais: o que é o homem e o que é a verdade, enigmas estes apresentados pela esfinge. "A esfinge é o próprio real, o ser, no qual e pelo qual somos e não somos. O mito do homem para se realizar tem de enfrentar o mito da esfinge, ou seja, o mito do real, o mito do ser em seu sentido." (CASTRO: 2005, p. 23)

$\mathrm{Na}$ era em que a ciência tem procurado determinar não só o ser como a própria verdade do real, a obra de arte ainda mantém o seu vigor. A obra de arte é sempre originária e instauradora de mundo. De todas atividades do homem é ela a mais antiga e originária. Em todas as civilizações, sempre houve e haverá maneiras diferentes de se experienciar o real através de atividades artístico-sagradas. $\mathrm{O}$ canto, a dança, a execução musical através de 
instrumentos mágico-encantatórios e a encenação de rituais do sagrado são formas diversas de o homem aproximar-se do extraordinário da arte.

A obra de arte não representa nada: ela manifesta o real. É através dela que o real se torna real como apresentação. A tensão advinda da obra de arte é uma das formas de o real se manifestar em seu fulgor e se retrair em seu estranhamento e mistério. Surge, então, conforme explica Manuel Antônio de Castro em A arte em questão: as questões da arte, um desafio: abandonar os "cômodos aconchegantes da casa das teorias" e pensar "a arte como questão". Segundo ele, esse é "um caminho que se refaz a cada interpretação e a cada resposta." A questão nunca pode se tornar objetiva ou subjetiva." (CASTRO: 2005 , p. 8) Ela antecede a cada ser humano e, portanto, não pode ser apreendida pelo pensamento racional. A fim de aproximar-se da arte como questão, é imprescindível permitir que o exercício intelectual passe a ser uma experienciação de vida.

O vocábulo "questão" origina-se do latim. Vem do verbo quaerere, cujo particípio é quaestum. Basicamente, ele tem o significado de desejar; indagar; pensar; perguntar. Como a arte é um enigma, ela é constituída de questões. $\mathrm{E}$ é exatamente por isso que não pode ser explicada por meio de definições, classificações e conceitos. É necessário examinar a arte, desejá-la e indagá-la através da força do pensamento. Entregar-se aos conceitos é deixar que a resposta se sobreponha às questões. As respostas pensam que são capazes de resolver as questões por meio da exatidão e precisão do conhecimento. De fato, a maior parte dos conceitos nascem da lógica e da linguagem matemática. São eles que servem de suporte para determinadas metodologias presas a teorias: o método dedutivo, o indutivo e o experimental. Muito diferente disso, pensar a arte exige um outro tipo de abordagem: deixar-se envolver pela magnitude das questões: "As questões não dependem do pensador. Não é ele que tem ou não tem as questões. As questões é que nos têm. Nós, cada um de nós é uma doação das questões. Elas constituem o que nos é próprio. Porém, para serem apropriadas exigem uma dura e assídua experienciação." (CASTRO: 2005, p. 14) 
A obra de arte debruça-se sobre si própria; entretanto, apesar de refletirse em si mesma, como revela um mundo, "faz ver de um modo novo nosso universo cotidiano". (HAAR: 2000, p. 27) Fundamentalmente, a obra de arte não visa à alusão de algo mais além dela mesma. Ela não se refere, conforme o pensamento de muitos, a um outro mundo. Ela apresenta referências próprias.

$\mathrm{Na}$ obra de arte, a verdade é posta em obra. O ser do ente tem a possibilidade de aceder ao seu brilho permanente. "A essência da arte seria então o pôr-se-em-obra da verdade do ente". (HAAR: 2000, p. 30) É possível concluir, portanto, que, na obra, não se faz presente uma reprodução do ente singular das coisas. Heidegger constata que o nosso questionamento a respeito da obra encontra-se conturbado, uma vez que não estamos interessados em indagar a respeito do operar que se manifesta na obra. Esse tipo de redução é reforçado pela Estética, pois ela vê a obra de arte "sob o domínio da interpretação tradicional de todo o ente enquanto tal". (HAAR: 2000, p. 30) E a partir disso, tenta aproximar-se da obra através de algum tipo de paradigma, já que tudo deve se transformar em conceito para ser compreendido. Ismos e mais ismos ecoam na voz de teóricos e especialistas, que influenciados por modismos passam a enquadrar o ser humano conceitualmente. Como conseqüência desse olhar aprisionador, o operar da obra de arte se retrai, pois essa pretensão conceitual não permite a abertura para o aberto da arte.

A origem da obra de arte é a própria arte. E a arte passa a ser real na obra de arte. A obra abre o ser do ente, de uma maneira bem particular. De fato, nessa abertura ocorre o desocultar da verdade do ente. Na obra de arte, a verdade do ente é posta em obra na própria obra. A arte coloca em operação a verdade, num constante velar e desocultar. O acontecimento da verdade achase em obra dentro da própria obra.

Em "Do caminho do criador", uma das seções de Assim falou Zaratustra, Friedrich Nietzsche já se mostrava preocupado com alguns aspectos que se encontram envolvidos na criação artística. Segundo Nietzsche, o caminho que conduz à liberdade artística e pessoal deve ser trilhado em completo afastamento de qualquer noção de rebanho. Para isso, faz-se necessário que o 
homem escape da obrigação de mentir em rebanho, em um estilo obrigatório a todos. (NIETZSCHE: 2000, p. 57)

"O que procura, facilmente se perde a si mesmo. Todo o isolamento é um erro". Assim fala o rebanho. E tu pertenceste ao rebanho durante muito tempo. Em ti também ainda há de ressoar a voz do rebanho. E quando disseres: "Já não tenho uma consciência comum convosco", isso será uma queixa e uma dor. (NIETZSCHE: 1999, p. 60 e 61)

Tal abandono somente se torna possível de três maneiras: através da procura da solidão, da superação do ressentimento e da renovação. (JARDIM: 2000, p. 1) A solidão que Nietzsche preconiza não significa simplesmente ausentar-se de maneira passiva e estática, pois isso implicaria uma inserção em um mero comportamento dogmático. "A existência dogmática vive dentro de um mundo desde sempre dado, desde sempre já feito, e não lhe ocorre pôr seriamente em dúvida este mundo". (SARTRE apud JARDIM, 2000: p. 1 e 2) Para Nietzsche, solidão significa busca de convivência com o que não é explícito, com o obscuro. Na solidão, o homem fica á deriva de inusitadas formas de comunicação e busca transcender os limites padronizados.

A solidão é "um conviver desarmado, um confrontar-se com a experiência sem os recursos de qualquer conhecimento, um encontrar-se corpo a corpo". (BUZZI: p.2000, p. 185) Para chegar a essa solidão, deve-se permitir que o pensamento viaje livre de preconceitos e de todo suposto saber científico. Esta é a aventura mais ousada a que o homem pode se lançar. Devido ao medo que têm da solidão, muitas pessoas não chegam a encontrarse consigo mesmas e muito menos com os outros. Mas o conselho de Zaratustra é diferente:

"Foge, meu amigo, para o teu isolamento! Vejo-te aturdido pelo ruído dos grandes homens e crivado pelos ferrões dos pequenos. Dignamente sabem calar-se contigo os bosques e os penedos. Assemelha-te de novo à tua árvore querida, a árvore de forte ramagem que escuta silenciosa, pendida para o mar.

Onde cessa a solidão principia a praça pública, onde principia a praça pública começa também o ruído dos grandes cômicos e o zumbido das moscas venenosas.

(...)

As fontes profundas precisam esperar muito para saber o que caiu na profundidade. 
Tudo quanto é grande passa longe da praça pública e da glória. Longe da praça pública e da glória viveram sempre os inventores de valores novos. Foge, meu amigo, para a soledade; vejo-te aqui aguilhoado por moscas venenosas." (NIETZSCHE: 1999, p. 53 e 54)

O segundo aspecto a ser observado a fim de se chegar à liberdade é a superação do ressentimento. A busca do isolar-se não deve ser acompanhada do ressentimento. O ressentimento como ódio é fruto da moral da doxa e acaba por gerar ao utilitário uma espécie de subordinação de valores; portanto, tornase incapaz de planear o libertar-se. O ressentimento é, de fato, uma "incubação de impossibilidades e não configura movimento, não transcende e não encontra caminho algum; em geral não aponta, e se, e quando aponta, aponta em direção a um senso comum, no sentido da fixação, da estagnação, da imobilidade.(JARDIM: 2000, p. 2)

O último aspecto a ser observado pelo criador que deseja libertar-se é o vigor do novo. A renovação é condição sine qua non para o libertar-se. O vigor do novo manifesta-se por meio da ambição de uma nova ordenação das ações causais, a qual garanta, de fato, uma original estrutura de relações. Faz-se necessária a indagação por novos princípios e fundamentos, pois nestes

outras relações se apresentam, e nesse apresentar-se exibem
e exigem um des-atrelamento ao sistema de valores vigente,
uma des-crença no "com"-sagrado desde sempre, e cria a
expectativa de inclusão, de modificação, e de interferência
nesse "com". A nova força é libertar-se pela operação de
um re-articular-se com o mundo, a partir da possibilidade de
viver a con-vivência da superação dos limites e da constante
quebra dos elos, e a partir dessa possibilidade construir a
passagem ao libertar-se. (JARDIM: 2000, p.. 3 e 4)

Para os pensadores originários, a arte não estava ligada às noções de belo e de beleza, mas sim à phýsis. Os primeiros pensadores consideravam a arte próxima à phýsis porque o vigor existente em ambas possibilita o desabrochar e o permanecer. A phýsis era o nome do ser. "Nada escapava do seu domínio, nem mesmo os contrastes, uma vez que a phýsis era aquela unidade originária que congregava tanto aquilo que saía e brotava (movimento), quanto o que se retinha e permanecia (repouso)." (MICHELAZZO: 1999, p. 29) 
Os pensadores originários não separavam o real em dois grandes blocos: o sensível e o supra-sensível. A noção de unidade era algo intrínseco ao seu modo de pensar. A realidade se apresentava a eles de maneira extraordinária, como se fosse um caleidoscópio, ao mesmo tempo que se mostrava cheia de encantamentos e perigos por todos os lados. Esses pensadores buscavam chegar à unidade oculta no interior de cada contraste. "O fundo escuro da caverna e a claridade do sol na pradaria eram, para eles, formas ou manifestações de uma única realidade, porque procediam de uma mesma fonte." (MICHELAZZO: 1999, p. 29)

Heráclito chegou a afirmar que um para ele valia mil. Todo o seu pensamento é marcado pela preocupação com a unidade. "Auscultando não a mim mas ao Logos, é sábio concordar que tudo é um. (ANAXIMANDRO: 1999, p. 71) Heráclito faz referência ao poeta Hesíodo, considerado como o mestre de quase todos, para o qual não havia distinção entre dia e noite (uma forma de enfatizar a unidade). Uma imagem freqüentemente evocada por Heráclito é a do círculo, pois este é capaz de reunir princípio e fim na sua circunferência. Em todas as direções (para cima e para baixo), o caminho é um e o mesmo.

Heráclito via também no fogo um elemento essencial, o qual possibilita a síntese de extremos. Ao sobrevir o fogo, todas as coisas serão distintas e reunidas. A importância atribuída ao fogo é tão grande que este chega a ser comparado ao ouro. "Pelo fogo tudo se troca e por tudo, o fogo; como pelo ouro, as mercadorias e pelas mercadorias, o ouro." (ANAXIMANDRO: 1999, p. 75)

A investigação e o pensamento eram, de fato, pontos centrais para Heráclito e os outros pensadores. É enfatizada a necessidade de que os homens sejam amantes da sabedoria, o que certamente os levará à investigação de muitas coisas. Para os pensadores originários, "pensar não era uma atividade ou faculdade em si, mas profundamente imbricada com aquilo que se apresenta, que brota". (MICHELAZZO: 1999, p. 30) Portanto, o pensar estava intimamente ligado à própria phýsis. Mesmo a reflexão livre sobre qualquer coisa não é constituída por uma completa independência daquilo que 
se manifesta; muito pelo contrário, mantém com ele uma conexão íntima. Todos sempre seguem de maneira reflexiva o que lhes foi apresentado.

Em Heráclito, a unidade originária entre ser e pensar é bastante evidente. "Pensar é a maior coragem, e a sabedoria, acolher a verdade e fazer com que se ausculte ao longo do vigor." (ANAXIMANDRO: 1999, p. 89) Heráclito declara que é possível a todos os homens conhecerem-se a si próprios, conhecimento este tido como inseparável do pensar. Na verdade, "pensar reúne tudo". (ANAXIMANDRO: 1999, p. 89)

Os pensadores originários diferem dos assim chamados "filósofos", pois "o destino histórico de seu pensamento não provém da objetividade dos conhecimentos mas do vigor do pensamento". (ANAXIMANDRO: 1999, p. 81) O pensamento dos primeiros pensadores gregos não deve ser pensado, empregando-se apenas os recursos da ciência e da filosofia. Ao interpretar um pensamento, se alguém se atém apenas aos textos, limitando-se ao sentido objetivo, certamente demolirá aquilo que sustenta o vigor desse pensamento. (LEÃO: 1991, p. 81)

A partir de Platão, a obra de arte começa a passar por um processo de rebaixamento e condenação. Para ele, a arte encontra-se no nível mais baixo das atividades e realizações. A obra de arte é tida como um produto grosseiro, enganador e altamente prejudicial. Não é de se admirar que o artista para ele seja um indivíduo inocente e ingênuo.

A depreciação ontológica da obra de arte é levada a cabo por Platão no décimo livro de $A$ República. A fim de que se tenha uma cidade realmente perfeita, Platão propõe que não se aceite a "poesia de caráter mimético". Para ele, todas as obras dessa espécie "afiguram ser a destruição da inteligência dos ouvintes, de quantos não tiveram como antídoto o conhecimento da sua verdadeira natureza."(PLATÃO: 2000, p. 293)

É através da noção de mimesis que se desenvolve a condenação da obra de arte. A arte é vista por Platão como algo que se encontra distante da verdade, pois é um tipo de imitação, uma aparência da própria aparência. Homero, o principal responsável pela paidéia grega até então, passa a ser vítima de vários ataques, já que, para Platão, a poesia se acha no terceiro 
nível de distanciamento em relação à verdade. O poder de influência para o bem de Homero é colocado em cheque:

"Meu caro Homero, se, relativamente à virtude, não estás afastado três pontos da verdade, nem és um fazedor de imagens, a quem definimos como um imitador, mas estás afastado apenas dois, e se foste capaz de conhecer quais são as atividades que tornam os homens melhores ou piores, na vida particular ou pública, diz-nos que cidade foi, graças a ti, melhor administrada, como sucedeu com a Lacedemônia, graças a Licurgo, e com muitas outras cidades, grandes e pequenas, devido a muitos outros? Que Estado te aponta como um bom legislador que veio em seu auxílio? A Itália e a Sicília indicam Carondas, e nós, Sólon. E a ti, quem?" (PLATÃO: 2000, p. 298)

No pensamento de Platão, a imitação poética não está baseada em conhecimento algum. "Os poetas não sabem do que falam. Seriam incapazes de explicar o que eles imitam." (HHAR: 2000, p. 20) Dessa forma, Platão afirma que, mesmo Homero falando sobre a educação dos cidadãos e a administração das cidades, se lhe perguntarmos sobre as técnicas envolvidas nessas atividades, ele não saberá informar os princípios que as regem. Os poetas são apresentados como indivíduos ignorantes:

Logo, quanto a estas questões, estamos, ao que parece, suficientemente de acordo: que o imitador não tem conhecimentos que valham nada sobre aquilo que imita, mas que a imitação é uma brincadeira sem seriedade; e os que se aventuram à poesia trágica, em versos iâmbicos ou épicos, são todos eles imitadores, quanto se pode ser. (PLATÃO: 2000, p. 301)

A partir dessa maneira de pensar, a arte é, então, excluída da pólis; e os poetas, expulsos, pois ambos se mostram destituídos da capacidade de enriquecimento tanto da prática, quanto da teoria. De acordo com Platão, a arte está associada à infantilidade do homem. A imitação não passa de um jogo infantil, sem seriedade alguma. "A tragédia, que nos faz ter prazer com o espetáculo da desgraça, enfraquece o elemento racional que há em nós; ela não nos ensina a permanecermos calmos e corajosos diante da infelicidade que nos atinge." (HAAR: 2000, p. 20) O que a arte trágica, de fato, ensina é a imoralidade, além de crimes e paixões. "Esta condenação moral da arte pesou 
mais severamente na tradição que sua condenação como ignorância e fabricação de ilusões." (HAAR: 2000, P. 20)

A metafísica, o fundamento no qual está edificado todo o pensamento do Ocidente, procurou, nos diversos momentos de sua história, sempre representar o homem pelo esquecimento do Ser. Dentro dessa maneira de pensar, a arte é tida como uma atividade inferior, de segunda categoria. Heidegger, no assim chamado "Segundo Momento" de seu pensamento filosófico, procura superar a metafísica através de um movimento regressivo, "mostrando que o esquecimento em vigor na metafísica provém de uma iluminação originária da Verdade do Ser, que é a figura epocal da vicissitude histórica, instaurada no princípio da existência grega". (LEÃO: 1991, p. 119)

A criação artística é vista por Heidegger como o eco de um combate originário, no qual é disputada a partilha entre o que é descoberto e aquilo que se encontra velado. A verdade da obra "advém como o combate entre clareira e ocultação, na reciprocidade adversa entre mundo e terra". (HEIDEGGER: 19991, p. 50) A obra de arte não pode ser vista como uma fabricação arbitrária ou uma mera ficção. "Ela só é uma obra porque nela aparece a relação mundoterra, clarão-recolhimento (manifesto-oculto), relação que constitui a essência da verdade". (HAAR: 2000, p. 88) A verdade existente na obra de arte não é decorrência do fato de ela imitar uma determinada realidade exterior ou mesmo uma dimensão interior, mas sim porque ela encarna em um ente a relação de desocultamento.

A obra de arte realiza um combate ao instituir um mundo e produzir uma terra. A obra é a própria instigação desse combate, o qual ocorre não a fim de que ela esmague o combate e o aplane, num acordo tácito, mas sim para que o combate se fortaleça, ou seja, que o combate mostre todo o seu vigor como combate. O ser-obra da obra se constrói a partir da disputa do combate entre mundo e terra. É na intimidade que o combate atinge o apogeu e é nessa disputa que se dá a unidade da obra.

A disputa do combate é Sammlung, recolecção definitiva e superada da mobilidade da obra. A quietação da obra chega à sua essência na intimidade do combate, descansando em si própria. A obra está em obra, está a operar a 
verdade, velando e des-velando. Somente é possível ter acesso ao que está em obra na obra a partir do repouso da obra.

A constituição de um mundo e de uma terra encontra-se no ser-obra da obra. Existe entre esses dois traços uma relação de co-pertença: ambos se pertencem na unidade do ser-obra. Tal unidade é percebida no momento em que dirigimos a nossa mente para o Insichstehen,o estar-em-si da obra. É aí que nos voltamos para a quietação fechada do repouso em si.

Terra é o lugar para onde a obra se retira e o que ela faz ressair quando se retira. Ela é das Hervorkommend-Bergende, o que ressai e ao mesmo tempo oferece guarida. A terra é incansável e aí está por nada. É sobre a terra que o homem histórico inaugura o seu habitar no mundo. A obra produz terra à proporção que instala um mundo. A obra impulsiona a terra para a abertura de um mundo e é lá que ela permanece. A obra permite que a terra seja feita terra. (HEIDEGGER: 1999, p. 36)

A terra somente se revela quando é revestida de ocultamento. Assim, ela despedaça todo esforço de intromissão nela. Ela chega a esfacelar toda impertinência calculadora. Só é possível ter acesso à abertura iluminada da terra se ela for salvaguardada como aquela que é unerschliessbar, a insondável, que se afasta diante da exploração desmedida, a que permanece fechada. Na totalidade da terra, todas as coisas se ligam numa harmonia recíproca. Em sua essência, a terra é Sich-Verschliessende, a que fecha em si própria.

Produzir a terra é exatamente conduzi-la à sua abertura como o que fecha em si mesma. Tal produção é Herstellung, a qual permite que a obra se realize, retirando-se da terra. Não se deve aproximar do fechado da terra no rigor da uniformidade, mas sim lançando mão de uma inesgotável plenitude de formas simples. Por exemplo, o pintor emprega a tinta na criação de um quadro, contudo não permite que a cor se desgaste; ao invés disso, ela adquire brilho e luz. Da mesma maneira, o poeta faz uso da palavra, mas não a desgasta como o fazem aqueles que escrevem habitualmente. Ele recupera o vigor originário da palavra, explorando toda a sua força de ambigüidade, pois 
toda poesia é por excelência ambígua. Melhor dizendo, o poeta permite que a palavra permaneça verdadeiramente uma palavra.

A terra abre a clareira daquilo sobre o qual o homem funda o seu habitar. Terra não é apenas uma massa de matéria ou a imagem meramente astronômica de um planeta. A terra é bergen, onde o erguer reúne aquilo que se ergue, e é nesse erguer que a terra se firma como o que dá guarida.

Um templo grego não imita nada. Ele se ergue nos vales e a construção encerra a forma do deus. O deus se faz presente no templo graças ao próprio templo. O aproximar-se do deus é o que demarca o ambiente como sagrado; entretanto, o templo não se esvai na indefinição. É o templo como obra que agrega e arrasta para junto de si as vias em sua unidade. É nesse congregar que o homem percebe o delineamento do seu destino - vitória e derrota, nascimento e morte, infelicidade e prosperidade se constroem como sentido. A amplitude resultante da abertura de relações é que constitui o mundo de um povo histórico. É somente a partir do mundo que ele regressa a si próprio a fim de cumprir o que lhe é destinado.

O edifício se encontra firme sobre o chão, chegando a resistir a toda tormenta que se aproxima dele. É o brilho que advém da sua pedra que coloca em destaque o fulgor do dia e a escuridão da noite. O templo como obra permite a abertura de um mundo e, simultaneamente, o reconduz à terra que, a partir daí, se faz notar como heimatlich Grund, o solo pátrio.

Em seu estar-aí, o templo apresenta aos homens uma visão de si mesmos, que se manterá aberta se a obra permanecer como obra e o deus não se afastar dela. Movimento idêntico ocorre com a obra da linguagem. Numa tragédia grega, por exemplo, é travada uma batalha entre os antigos deuses e os novos. Nada é apresentado ou representado. No momento em que a obra da linguagem emerge no dizer de um povo, ela não visa simplesmente a discorrer sobre tal luta, mas sim a revigorar o dizer de um povo, permitindo que cada palavra essencial abrace a luta e proponha uma decisão entre o que é ou não sagrado.

A instalação de uma obra (Aufstellen) ocorre quando ela se acomoda numa coleção. Aufstellen diverge, todavia, de Erstellung, que seria a instalação 
no sentido de erguer uma estátua ou uma obra arquitetônica. Aufstellen tem como significado erigir no sentido de glorificar, de consagrar. Instalar, aqui, não diz respeito simplesmente a colocar. Consagrar significa abrir o sagrado como sagrado, invocando o deus através do aberto do seu advento.

A glorificação como reverência à onipotência do deus participa da consagração obra. É o respeito à dignidade e ao esplendor da divindade. Convém destacar que dignidade e esplendor não são propriedades do deus; muito pelo contrário, o advento do deus se dá na dignidade e no esplendor.

É no reflexo desse esplendor que brilha o mundo. A obra abre um mundo e o sustenta em uma permanência que domina. A manifestação da obra é um erigir que consagra e ao mesmo tempo glorifica. Erigir significa permitir a abertura do justo em relação à medida que o essencial é. O ser-obra da obra requer a glorificação. A obra no seu ser-obra é instaladora. Ser obra implica automaticamente uma instalação de mundo.

Mundo não é simplesmente a reunião das coisas que existem e nem muito menos uma moldura imaginada e representada em acréscimo ao que já existe. O mundo mundifica: ele se põe além do que é palpável e apreensível. O mundo não é um objeto que se encontra diante de nós e que pode ser apreendido: "O mundo é o sempre inobjectal a que estamos submetidos enquanto os caminhos do nascimento e da morte, da bênção e da maldição nos mantiverem lançados no Ser." (HEIDEGGER: 1999, p. 35)

A amplidão a partir da qual se percebem os atos de bondade dos deuses é apresentada ou recusada no mundificar. A obra como obra permite a abertura do espaço para a amplidão. Abrir espaço significa libertar o livre do aberto e constituir este espaço do livre no grupo de traços que lhe pertencem. A obra como obra instala um mundo e mantém o aberto em sua abertura. Tal instituição de mundo se dá a partir do erigir do mundo.

O mundo é aberto da abertura dos diversos caminhos das decisões de um povo histórico. A terra é o que ressai no vazio e se recolhe freqüentemente, oferecendo guarida. É impossível apaziguar o conflito entre o mundo e a terra. Um diverge do outro; entretanto, não podem ser separados. 
O mundo instala-se na terra e a terra emerge através do mundo. A relação entre eles, todavia, não desemboca na unidade vazia da antítese. No seu repousar, o mundo anseia por sobrepujar a terra - na sua abertura, ele não permite que coisa alguma se mantenha fechada. Como aquela que recolhe e oferece guarida, a terra procura conter o mundo.

O combate no qual a terra e o mundo se encontram envolvidos é Streit, cuja essência geralmente é confundida com a disputa e a discórdia, numa associação quase que imediata com a destruição ou a perturbação. No combate essencial entre mundo e terra, os que participam do combate são conduzidos à afirmação das suas essências. No combate, cada um tem a preocupação de conduzir o outro para além de si mesmo. É dessa forma que o combate passa a ser mais combativo e o que é autenticamente.

Na obra, a verdade está a operar. Em toda a trajetória da metafísica, a idéia de verdade foi sempre associada à justeza de uma proposição, como se aquilo que é verdadeiro pudesse ser expresso por meio de um enunciado. Ou então, o verdadeiro é visto como oposição do que é falso, como é o caso do ouro falso. Verdadeiro é usado como sinônimo de autêntico, como aquilo que encontra uma correspondência no real e o real é o que na verdade é. Habitualmente, a verdade é vista como um ponto de convergência para o qual se dirige tudo que é verdadeiro. Para muitos, a essência da verdade está ligada a um conceito universal e genérico que representa o uno. Tal essência indiferente é, entretanto, a essência inessencial. A essência de alguma coisa consiste naquilo que o ente na verdade é. Só se consegue chegar a uma definição de essência verdadeira a partir da verdade do seu ser.

A verdade deve ser pensada partir da essência daquilo que é verdadeiro. É a desocultação do ente, Unverborgenheit, para os gregos, alétheia. Em sua essência, a verdade é não-verdade. Ela se encontra em um combate constante. A verdade é Lichtung, clareira, é um desvelamento que está a ocorrer. "Mas essa clareira do desvelamento do ente não é cena uniformemente aberta: o desvelamento só é em relação preservada com o velamento." (DUBOIS: 2004, p. 172 e 173) 
O combate entre terra e mundo não é Riss, um rasgão de um abismo. O combate é a intimidade que resulta da reciprocidade dos próprios combatentes, os quais são conduzidos pelo rasgão à sua unidade original a partir de um fundo único. O combate não só é Grundriss, um risco fundamental, mas também Auf-riss, um traçado que esboça os traços fundamentais do desocultar da clareira do ente. Tal rasgão conduz a contrariedade da medida e do limite a Umriss, contorno único que não permite que haja uma ruptura entre os adversários.

Somente é instituída a verdade como combate em um ente se o combate neste ente for aberto, de modo que ele mesmo é conduzido ao rasgão. O rasgão é Gefüge, a união de diâmetro e de contorno, de traçado e risco fundamental. Na obra de arte, a verdade se instala no ente, de maneira que ele mesmo passa a ocupar o aberto da verdade. Só ocorrerá esta ocupação se o rasgão se entregar ao que se fecha, àquilo que assoma no aberto.

O combate que é conduzido ao rasgão é colocado novamente na terra e, assim, ele é fixado. O ser-criado da obra é o ser estabelecido na Gestalt: ela é a forma, a juntura na qual o rasgão está disposto. Forma, aqui, refere-se à Stellen, que é o estatuir, e também à Ge-stell, que é, na verdade, o conjunto de tudo aquilo que estatui. É desse modo que a obra se apresenta à medida que é instalada e produz.

Faz-se necessário deixar que a obra seja uma obra, o que se denomina a salvaguarda da obra (Bewahrung). Aquilo que é criado não tem a possibilidade de tornar-se ser a menos que seja salvaguardado. A salvaguarda da obra é Innestehen, a instância na abertura do ente que ocorre na obra:

\footnotetext{
A salvaguarda da obra é a sóbria persistência no abismo de intranqüilidade da verdade que acontece na obra. (...) A salvaguarda da obra não isola os homens nas suas vivências, mas fá-los antes entrar na pertença à verdade que acontece na obra, e funda assim o ser-com-e-para-os-outros (das Für und Miteinandersein), como exposição (Ausstehen) histórica do seraí a partir da sua resolução com a desocultação. Em absoluto, o saber no modo da salvaguarda nada tem a ver com aquele conhecimento do erudito que saboreia o aspecto formal da obra, as suas qualidades e encantos. Saber, enquanto ter-
} 
visto, é um ser-decidido; é instância no combate que a obra dispõe no rasgão. (HEIDEGGER: 1999, p. 54 e 55)

A maneira correta de salvaguardar a obra é criada e mostrada somente pela própria obra. Em diferentes graus, a salvaguarda é proveniente do saber com diferente alcance e luminosidade. A salvaguarda da obra não está relacionada, de forma alguma, ao gozo estético puro e simples.

A arte é a salvaguarda criadora da verdade na obra. A essência da arte é o pôr-em-obra da verdade. Pôr-em-obra significa colocar em andamento, permitir que o ser-obra aconteça. Sendo assim, é possível afirmar que a arte é um devir e um acontecer da verdade, que jamais pode ser vista a partir do que é meramente habitual. O aberto da abertura e a clareira do ente apenas ocorrem quando a abertura que se origina da dejecção é projetada. A respeito da verdade da obra de arte, Heidegger escreve:

Na obra está em obra o acontecer da verdade. Podemos caracterizar a criação como o deixar-emergir (das Hervorgehenlassen) num produto (das Hervorgebrachtes). $\mathrm{O}$ tornar-se-obra da obra (das Werkwerden) é um modo do passar-a-ser e de acontecer da verdade. Na essência desta reside tudo. (...) A verdade é não-verdade, na medida em que Ihe pertence o domínio de proveniência do ainda-não-(des)ocultado, no sentido da ocultação. A verdade advém, como tal, na oposição entre clareira e dupla ocultação. (...) A verdade só acontece de modo que ela se institui por si própria no combate e no espaço de jogo que se abrem. Porque a verdade é a reciprocidade adversa entre clareira e ocultação. (HEIDEGGER:1999, p. 48 e 49)

Como velamento e des-velamento do ente, a verdade somente acontece quando se poetiza. "Toda arte, enquanto deixar-acontecer da adveniência da verdade do ente como tal, é na sua essência Poesia." (HEIDEGGER: 1999, p. 58) Como a essência da arte é o pör-em-obra da verdade, ela faz emergir um espaço aberto a partir da sua própria essência poetante no meio do ente. É neste espaço que tudo se apresenta de uma maneira diferente do habitual. A poesia é um modo do projeto de clarificação da verdade, do poeta no sentido lato; por conseguinte, todas as artes (a escultura, a arquitetura e a música) devem ser reconduzidas à poesia.

A poesia não é um inventar desvairado e nem muito menos um aventurar-se da representação no irreal. O universo da poesia não é o do 
devaneio e nem o da fantasia vaga: ele é decorrente do primado da língua que, ao apresentar as coisas como são, delineia a sua aparição através do clarão. (HAAR: 2000, p.93) "O que a Poesia, enquanto projeto clarificante, desdobra na desocultação e lança no rasgão da forma, é o aberto que ela faz acontecer e, decerto, de tal modo que, só agora o aberto em pleno ente traz este à luz e à ressonância." (HEIDEGGER: 1999, P.58) É na Poesia que a arte acontece. Tal instauração se dá numa construção tripla: oferta, fundação e princípio.

O poema não comunica um determinado tipo de conteúdo. Ele faz ressoar, na verdade, uma Grundstimmung, um tom fundamental, uma disposição de fundo, diferentes expressões do sagrado para o qual a poesia abre as portas. Todo pensamento vem à tona através desta disposição de fundo, pois toda poesia é pensante. Tal tonalidade não se restringe à especificidade de uma época, embora ela adquira feições diferentes em cada época. (HAAR: 2000, p. 96)

A poesia é o dizer projetante. Ela é a fábula que desoculta o ente. $\mathrm{O}$ dizer projetante é aquele que, ao preparar o dizível, abre portas também para o indizível do mundo. É desse dizer que um povo histórico recebe as questões da sua essência e do seu pertencer à história. A obra e a sua tonalidade não são determinadas pela história. É na obra que o homem tem acesso ao esboço da configuração profunda de uma época. Os homens somente possuem uma história devido à verdade se apresentar a eles, sendo instalada em suas obras. As obras de arte não são feitas por uma época - é em torno das obras que uma época específica é configurada e reconhecida como o que ela é.

\section{Conclusão}

A arte é histórica e é como história que ela é a salvaguarda criadora da verdade na obra. A palavra "história", aqui, não aponta simplesmente para o desdobrar dos acontecimentos. É a historiografia que se volta para a narração e descrição dos fatos que se desenrolam. "História é o despertar de um povo para a sua tarefa, como inserção no que lhe está dado." (HEIDEGGER: 1999, p. 62) É produzido um choque na história no momento em que a arte acontece: há um princípio e a história começa ou recomeça novamente. 
Como força instauradora, a arte é essencialmente histórica, o que não significa apenas que ela possui uma história, no sentido de acontecer dentro de uma seqüência cronológica, juntamente com outros fenômenos e transformações. A arte é histórica porque funda a própria história.

\section{Referências Bibliográficas}

ANAXIMANDRO et alii. Os pensadores originários. Trad. Emmanuel Carneiro Leão e Sérgio Wrublewski. Petropólis: Vozes, 1999.

BUZZI, Arcângelo R. Introdução ao pensar: o Ser, o Conhecimento e a Linguagem. Petrópolis: Vozes, 2000.

CASTRO, Manuel Antônio de. A arte em questão: as questões da arte. Rio de Janeiro: 7Letras, 2005.

DUBOIS, Christian. Heidegger: Introdução a uma leitura. Trad. Bernardo Barros Coelho de Oliveira. Rio de Janeiro: Jorge Zahar, 2004.

HAAR, Michel. A obra de arte: ensaio sobre a ontologia das obras. Rio de Janeiro: DIFEL, 2000.

HEIDEGGER, Martin. A origem da obra de arte. Trad. Maria da Conceição Costa. Lisboa: Edições 70, 1999.

JARDIM, Antônio. Do caminho do criador ao caminho do libertar-se. UFRJ: Rio de Janeiro, 2000.

LEÃO, Emmanuel Carneiro. Aprendendo a pensar. (vol. 1). Petrópolis: Vozes, 1991.

MICHELAZZO, José Carlos. Do um como princípio ao dois como unidade: Heidegger e a reconstrução ontológica do real. São Paulo: FAPESP, 1999.

NIETZSCHE, Friedrich. "Sobre verdade e mentira no sentido extra-moral". In: . Os pensadores. SP: Editora Nova Cultural, 2000.

Claret, 1999.

Assim falou Zaratustra. Trad. Pietro Nassetti. São Paulo: Martin

PLATÃO. A República. São Paulo: Martin Claret, 2000.

SANTOS, Roberto Corrêa dos. Modos de saber, modos de adoecer. Belo Horizonte: Editora UFMG, 1999.

Lendo Clarice Lispector. São Paulo: Atual, 1986.

SÓFOCLES. Édipo Rei. Rio de Janeiro: Ediouro, 2000. 